\title{
PENERAPAN MODEL PEMBELAJARAN THINK TALK WRITE (TTW) BERBANTU MEDIA CD INTERAKTIF PADA MATA PELAJARAN IPA TERHADAP HASIL BELAJAR SISWA
}

\author{
Azizatul Khusna, Joko Sulianto, dan Ari Widyaningrum \\ Universitas PGRI Semarang \\ Email: Azizatulkhusna7@gmail.com
}

\begin{abstract}
Abstrak
Penelitian ini bertujuan untuk menganalisis dan mengetahui perbedaan hasil belajar pretest dan posttest yang ditimbulkan dengan model pembelajaran Think Talk Write (TTW) berbantu media CD Interaktif pada mata pelajaran IPA terhadap hasil belajar siswa. Jenis penelitian adalah kuantitatif. Populasi adalah siswa kelas VI SD Negeri Mlatiharjo 02 Semarang dengan jumlah 40 siswa. Sampel yang digunakan merupakan sampling jenuh. Data penelitian diperoleh melalui instrumen penelitian terhadap hasil belajar siswa. Desain penelitian adalah Pre-Experimental Designs (non design) dengan jenis yang diambil adalah One-Group Pretest-Posttest Design. Data penelitian diperoleh melalui observasi, tes, dan dokumentasi. Hasil penelitian menunjukkan bahwa terdapat perbedaan rata-rata hasil pretest dan posttest pada hasil belajar siswa kelas eksperimen. Rata-rata hasil pretest sebesar 59,5 dan rata-rata posttest sebesar 74,5. Berdasarkan perhitungan uji t satu pihak diperoleh $t_{\text {hitung }}$ $=7,252$. Dari daftar distribusi dengan $\mathrm{db}=\mathrm{n}-1=40-1=39$. Untuk $\alpha=5 \%$ maka harga $t_{\text {tabel }}$ 1,684. Dari perhitungan uji t diperoleh $t_{\text {hitung }}>t_{\text {tabel }}$ yaitu $7,252>1,684$. Dengan demikian maka $H_{o}$ ditolak dan $H_{a}$ diterima. Dan hasil uji ketuntasan siswa diperoleh hasil pretest dengan 17 siswa yang tuntas belajar atau $42,5 \%$ dan 23 siswa yang belum tuntas atau $5,75 \%$ dan hasil posttest dengan 35 siswa tuntas atau 87,5\% dan terdapat 5 siswa yang belum tuntas atau $12,5 \%$. Terdapat perbedaan yang signifikan antara hasil belajar pretest dan posttest setelah menggunakan model pembelajaran Think Talk Write (TTW) berbantu media CD Interaktif pada mata pelajaran IPA terhadap hasil belajar siswa kelas VI SD Negeri Mlatiharjo 02 Semarang tahun ajaran 2016/2017.
\end{abstract}

Kata Kunci: Think Talk Write, CD Interaktif, Hasil Belajar

\section{APPLICATION OF THINK TALK WRITE LEARNING MODEL (TTW) ASSISTED INTERACTIVE CD MEDIA IN LESSON OF SCIENCE ON STUDENT LEARNING RESULT}

\begin{abstract}
This research aims to analyze and find out the difference a result learn pretest and posttest posed with model learning Think Talk Write (TTW) berbantu Interactive CD media on subjects the student learning outcomes towards IPA. This type of research is quantitative. The population is grade VI SD Negeri Mlatiharjo 02 Semarang with the amount of 40 students. The sample used is a sampling of saturated. Research data obtained through research instrument against the results of student learning. Design research is the PreExperimental Designs (non design) and the kind that is taken is the One-Group PretestPosttest Design. Research data obtained through observation, tests, and documentation. The results showed that there is a difference of the average results of pretest and posttest on learning results students class experiments. The average results of 59.5 pretest and posttest average of 74.5. $T$ test calculation based on one party obtained thitung $=7.252$. From a distribution list with $d b=n-1=40-1=39$. For $\alpha=5 \%$ the price t_tabel 1.684. The calculation of the test $t$ obtained t_hitung > t_tabel i.e. $7.252>1.684$. Thus $H \_o$ H_a rejected and accepted. Ketuntasan test results and student pretest results obtained with 17
\end{abstract}


students who thoroughly learned or $42.5 \%$ and 23 students who hadn't or $5.75 \%$ and posttest results with 35 students and discharging, or $87.5 \%$ and there are 5 students who hadn't or $12.5 \%$. There is a significant difference between the results of a pretest and posttest study after using the model learning Think Talk Write (TTW) berbantu Interactive CD media on subjects NATURAL SCIENCE learning outcomes against grade VI SD Negeri Mlatiharjo 02 Semarang 2016/2017 school year.

Keywords: Think Talk Write, Interactive CD, learning result

\section{PENDAHULUAN}

Belajar adalah proses transfer ilmu yang dilakukan oleh guru kepada siswa baik secara pengetahuan maupun sikap yang dapat Undang-undang Nomor 20 Tahun 2003 tentang Sistem Pendidikan Nasional, pasal 1 ayat 1 menyatakan bahwa pendidikan adalah usaha sadar dan terencana untuk mewujudkan suasana belajar dan proses pembelajaran agar siswa secara aktif mengembangkan potensi dirinya untuk memiliki kekuatan spiritual, keagamaan, pengendalian diri, kepribadian, kecerdasan, akhlak mulia, serta ketrampilan yang di perlukan dirinya, masyarakat, bangsa, dan negara. Dan pada dasarnya pendidikan yang ada dalam Sekolah Dasar pada umumnya bertujuan untuk mengembangkan sikap, memberikan sarana untuk mengembangkan sikap dan pengetahuan peserta didik agar mampu hidup bermasyarakat serta mempersiapkan peserta didik untuk melanjutkan jenjang pendidikan yang lebih tinggi. Dalam pelaksanaan proses belajar mengajar, tugas utama guru adalah mendidik, mengajar, melatih, bahkan memfasilitasi siswa untuk mencapai taraf kemampuan atau kecerdasan, budi pekerti yang luhur, dan kemampuan mengolah keterampilan yang optimal. Agar semuanya bisa tercapai, guru harus mampu berperan sesuai tugasnya dan mampu menguasai berbagai kemampuan dan keahliannya. Guru juga di tuntut untuk mampu menguasai mata pelajaran dan mampu menyajikan pembelajaran yang lebih menarik dalam kegiatan belajar mengajar.

Pendidikan memegang peranan yang sangat penting di berbagai sektor kehidupan. Pendidikan yang berkualitas akan menciptakan sumber daya manusia yang berkualitas pula. "Karena itu pendidikan di Indonesia terus diperhatikan dan ditingkatkan dengan berbagai cara, diantaranya mengeluarkan undang-undang sistem pendidikan nasional, mengesahkan UU kesejahteraan guru dan dosen serta mengadakan perubahan kurikulum yang disesuaikan dengan kebutuhan zaman" (Hamdayama, 2015:135). Belajar merupakan proses internal yang kompleks. Yang terlibat dalam proses internal tersebut adalah seluruh mental, yang meliputi ranah kognitif, afektif, dan psikomotorik. Dari segi guru proses belajar tersebut dapat diamati secara tidak langsung. Artinya proses belajar merupakan proses internal siswa tidak dapat diamati, akan tetapi dapat dipahami oleh guru. Proses belajar tersebut tampak melalui perilaku siswa mempelajari bahan belajar (Aunurrahman, 2009:48).

Kenyataannya di lapangan menunjukkan bahwa proses pembelajaran hanya menggunakan cara mengajar yang biasa-biasa saja, tanpa menggunakan inovasi pembelajaran yang berdampak pada tingkat ketercapaian tujuan pembelajaran yang kurang maksimal. Salah satu inovasi pembelajaran yang akan membuat siswa lebih tertarik dalam kegiatan belajar mengajar adalah menggunakan model pembelajaran yang tepat. Ketidaktepatan penggunaan model pembelajaran yang biasa saja (konvensional) menjadi salah satu penyebab kurang tercapainya tujuan pembelajaran secara maksimal. Dalam hal ini, guru harus mampu mengelola kelas dan menciptakan situasi pembelajaran yang kondusif, agar pembelajaran didalam kelas menjadi lebih semangat dan siswa tidak merasa bosan. Sehingga siswa lebih 
berantusias dalam mengikuti kegiatan belajar mengajar. Menurut Kamus Besar Bahasa Indonesia (KBBI) pengertian penerapan adalah perbuatan menerapkan, penerapan merupakan suatu perbuatan mempraktikkan suatu teori, metode, dan hal lain untuk mencapai tujuan tertentu.

Untuk mengatasi masalah tersebut guru harus mampu menciptakan suasana pembelajaran yang menarik dan menyenangkan, kegiatan pembelajaran yang menyenangkan akan terwujud jika guru mampu mengelola kelas dengan baik, sehingga pembelajaran akan lebih efektif dan efisien. Untuk menciptakan suasana belajar yang menyenangkan guru harus mampu menerapkan model pembelajaran yang bervariasi yang sesuai dengan materi yang akan disampaikan. Guru harus mampu menerapkan model pembelajaran yang sesuai dengan mata pelajaran IPA supaya siswa lebih semangat dan berantusias dalam proses pembelajaran. Sehingga proses pembelajaran akan lebih bermakna dan tujuan pembelajaran yang diinginkan dapat tercapai.

Salah satu model pembelajaran yang dapat diterapkan yaitu model pembelajaran Think Talk Write (TTW). Model pembelajaran Think Talk Write (TTW) adalah model pembelajaran yang dimulai dari alur berfikir melalui bahan bacaan (menyimak, mengkritisi, dan alternatif solusi) selanjutnya berbicara dengan melakukan diskusi, presentasi, dan terakhir menulis dengan membuat laporan hasil diskusi maupun presentasi (Siregar \& Nara, 2014:66). Sedangkan menurut Iru \& Arisi (2012:67) menyatakan "Think Talk Write" merupakan model pembelajaran kooperatif yang kegiatan pembelajarannya yaitu lewat kegiatan berfikir (think), berbicara/berdiskusi (talk), bertukar pendapat (talk) serta menuliskan hasil diskusi (write) agar tujuan pembelajaran dan kompetensi yang diharapkan dapat tercapai. Jadi dapat disimpulkan Think Talk Write (TTW) merupakan model pembelajaran kooperatif yang dimulai dari alur berfikir (think) melalui kegiatan membaca, berbicara (talk) melalui kegiatan diskusi, bertukar pendapat, presentasi dan menulis (write) melalui kegiatan menuliskan hasil diskusinya.

Pendidikan Sekolah Dasar (SD) mengajarkan berbagai disiplin ilmu kepada peserta didik salah satunya yaitu mata pelajaran IPA. Dalam pengajaran IPA seorang guru dituntut untuk dapat mengajak anak didiknya memanfaatkan kemajuan teknologi sebagai sumber belajar. Sumber belajar adalah segala sesuatu yang dapat dimanfaatkan oleh siswa untuk mempelajari bahan dan pengalaman belajar sesuai dengan tujuan yang hendak dicapai (Sanjaya, 2011:172). Dalam hal ini seorang guru memiliki peranan yang sangat penting untuk membantu siswa dan memberikan bimbingan kepada peserta didik agar peserta didik mengetahui jenis-jenis sumber belajar dengan memanfaatkan kemajuan IPTEK.

Selain model pembelajaran, media pembelajaran juga berperan penting dalam keberhasilan belajar siswa. Media berasal dari bahasa latin dari kata "mediun" yaitu perantara sumber pesan dengan penerima pesan. Dalam dunia pendidikan, media adalah alat untuk menyampaikan pesanpesan dalam kegiatan pembelajaran yang akan disampaikan guru untuk siswa. Dengan adanya media, diharapkan pembelajaran lebih bermakna dan dapat meningkatkan hasil belajar siswa dalam kegiatan belajar mengajar (Huda, 2014:3).

Media CD Interaktif adalah salah satu media yang dapat menarik perhatian siswa dalam kegiatan belajar mengajar. CD Interaktif merupakan alternatif pemilihan media pembelajaran yang cukup menarik dan mudah untuk diterapkan dalam kegiatan pembelajaran. Karena CD Interaktif dapat memberikan suasana belajar yang menyenangkan dan sangat menarik. Sehingga manfaat yang diperoleh siswa dalam pembelajaran menggunakan media CD Interaktif adalah memberikan kemudahan siswa untuk memahami materi, sehingga siswa lebih mudah berinteraksi dan timbulnya suatu perubahan tingkah laku. 
Berdasarkan pengamatan di lapangan peneliti melihat kurangnya ketertarikan siswa dalam membaca materi dan menulis pada mata pelajaran IPA tentang sistem tata surya. Sistem tata surya terdiri atas matahari, planet, dan benda angkasa lainnya (Suhartanti, 2008:112). Dengan materi bacaan yang cukup banyak, sehingga membutuhkan pemahaman siswa dalam memahami benda-benda langit. Sehingga mata pelajaran IPA dianggap mata pelajaran yang membosankan. Padahal mata pelajaran IPA merupakan mata pelajaran yang berhubungan dalam kehidupan kita sehari-hari. Penggunaan model pembelajaran yang kurang tepat dalam pembelajaran IPA menjadikan siswa kurang aktif dalam kegiatan pembelajaran. Sehingga hasil belajarnya kurang optimal yang disebabkan oleh beberapa faktor, yang mendorong peneliti untuk melakukan penelitian di SD Negeri Mlatiharjo 02 Semarang.

Model pembelajaran Think Talk White (TTW) merupakan salah satu model pembelajaran yang dapat digunakan sebagai inovasi dalam pembelajaran IPA di SD Negeri Mlatiharjo 02 Semarang. Karena model pembelajaran tersebut melibatkan siswa untuk berpikir, berbicara, dan menulis. Model Pembelajaran Think Talk Write (TTW) dapat membantu siswa dalam kemampuan pemahaman dan komunikasi siswa, sehingga siswa lebih mudah memahami materi pembelajaran untuk mengkomunikasikan hasil pemikirannya.

Berdasarkan latar belakang diatas penulis mengadakan penelitian dengan judul "Penerapan Model Pembelajaran Think Talk Write (TTW) Berbantu Media CD Interaktif Pada Mata Pelajaran IPA Terhadap Hasil Belajar Siswa Kelas VI SD Negeri Mlatiharjo 02 Semarang Tahun Ajaran 2016/2017”. Berdasarkan permasalahan yang dikemukakan pada latar belakang, maka rumusan masalahnya adalah apakah ada perbedaan hasil belajar pretest dan postest pada kelas VI SD Negeri Mlatiharjo 02 Semarang dengan model pembelajaran Think Talk Write
(TTW) berbantu media CD Interaktif pada mata pelajaran IPA tahun ajaran 2016/2017? Sesuai dengan permasalahan yang telah diuraikan, maka peneliti ini bertujuan untuk mengetahui apakah ada perbedaan hasil belajar pretest dan postest pada kelas VI SD Negeri Mlatiharjo 02 Semarang dengan model pembelajaran Think Talk Write (TTW) berbantu media CD Interaktif pada mata pelajaran IPA tahun ajaran SD Negeri Mlatiharjo 02 Semarang Tahun Ajaran 2016/2017.

\section{METODE}

Penelitian ini dilaksanakan pada tanggal 2-4 Februari tahun pelajaran 2016/2017 di SD Negeri Mlatiharjo 02 Semarang pada siswa kelas VI menggunakan metode penelitian kuantitatif dengan desain penelitian PreExperiment Design berbentuk One Group Pretest-Posttest Design.

Jenis yang diambil adalah OneGroup Pretest-Posttest Design. Pada desain ini terdapat pretest, sebelum diberi perlakuan. Dengan demikian hasil perlakuan dapat diketahui lebih akurat, karena dapat membandingkan dengan keadaan sebelum diberi perlakuan (Sugiyono, 2010:110). Desain ini dapat digambarkan sebagai berikut:

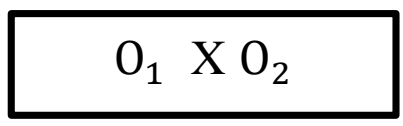

\section{Gambar 1. Bentuk Desain One-Group Pretest-Posttest Design}

Keterangan :

$\mathrm{O}_{1}$ : nilai pretest (sebelum diberi perlakuan)

$\mathrm{X}$ : perlakuan, yaitu menggunakan model pembelajaran Think Talk Write (TTW) berbantu media CD Interaktif "Saya Bisa" (Sistem tata surya dan alam semesta)

$\mathrm{O}_{2} \quad$ : nilai posttest (setelah diberi perlakuan)

Populasi adalah wilayah generalisasi yang terdiri atas objek/subjek yang mempunyai kualitas dan karakteristik 
tertentu yang ditetapkan oleh peneliti untuk dipelajari dan kemudian ditarik kesimpulannya. Jadi populasi bukan hanya orang, tetapi juga obyek dan benda-benda alam yang lain. Populasi juga bukan sekedar jumlah yang ada pada obyek/subyek yang dipelajari, tetapi meliputi seluruh karakteristik/sifat yang dimiliki oleh subyek atau obyek itu (Sugiyono, 2015: 117). Populasi yang digunakan dalam penelitian ini adalah seluruh kelas di SD Negeri Mlatiharjo 02 Semarang, tahun ajaran 2016/2017. Sugiyono (2015:118) mengatakan "Sampel adalah bagian dari jumlah dan karakteristik yang dimiliki oleh populasi tersebut". Sampel pada penelitian ini adalah kelas VI di SD Negeri Mlatiharjo 02 Semarang. Sugiyono (2015:118) mengatakan "Teknik sampling adalah teknik pengambilan sampel". Pengambilan sampel dilakukan dengan sedemikian rupa sehingga diperoleh sampel (contoh) yang benarbenar dapat berfungsi sebagai contoh atau dapat menggambarkan keadaan populasi yang sebenarnya. Teknik sampling pada dasarnya dikelompokkan menjadi dua, yaitu probability sampling dan nonprobability sampling. Teknik sampling yang digunakan dalam dalam penelitian ini adalah nonprobability sampling dengan jenis sampling jenuh. Sampling jenuh adalah teknik penentuan sampel bila semua anggota populasi digunakan sebagai sampel. Hal ini bila jumlah populasi relatif kecil, karena subjeknya kurang dari 100 jadi sampel penelitiannya sama dengan populasinya.

Teknik pengumpulan data merupakan langkah yang paling utama dalam penelitian, karena tujuan utama dari penelitian adalah mendapatkan data. Tanpa mengetahui teknik pengumpulan data, maka peneliti tidak akan mendapatkan data yang memenuhi standar data yang ditetapkan (Sugiyono, 2015:308). Penggunaan teknik dan alat pengumpul data yang tepat memungkinkan diperolehnya data yang objektif.

Dalam penelitian ini, ada beberapa teknik pengumpulan data yaitu: 1) Teknik pengumpulan data dengan observasi digunakan bila, penelitian berkenaan dengan perilaku manusia, proses kerja, gejala-gejala alam dan responden yang diamati tidak terlalu besar (Sugiyono, 2016:203). Dalam observasi peneliti dapat melibatkan diri dalam situasi subjek yang diobservasi, tetapi dapat pula dilakukan tanpa melibatkan diri dalam situasi subyek, jadi pelaksana tidak hanya sebagai penonton. Penelitian ini menggunakan lembar observasi (pengamatan) untuk mengukur sikap siswa pada proses pembelajaran. Observasi dilakukan siswa siswa kelas VI SD Negeri Mlatiharjo 02 Semarang yang berjumlah 40 siswa melalui pengamatan saat penelitian.

\section{Tabel 1. Kisi-kisi Penilaian Sikap}

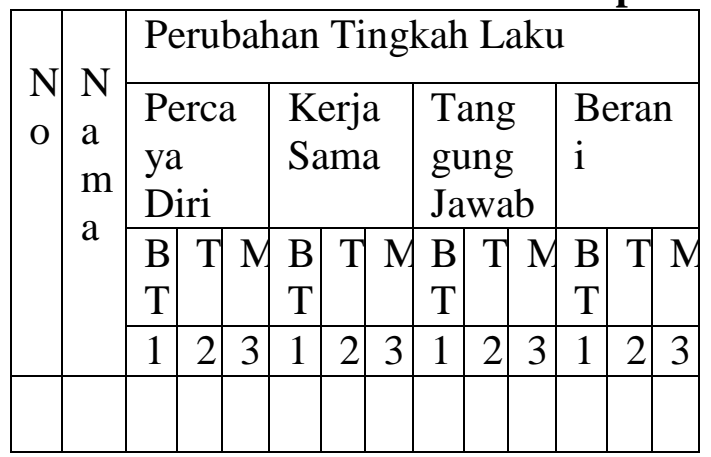

2) Dokumen merupakan catatan peristiwa yang sudah berlaku. Dokumen dalam bentuk tulisan, gambar, atau karya-karya monumental dari seseorang. Dokumentasi dalam penelitian ini digunakan untuk mendapatkan dokumen sekolah mengenai nama siswa, jumlah siswa, dan data-data yang diperlukan dalam penelitian (Sugiyono, 2015:329). 3) Ysh \& Maryadi (2015:170) menyatakan tes ialah seperangkat rangsangan (stimulus) yang diberikan kepada seseorang dengan maksud untuk mendapat jawaban yang dapat dijadikan sebagai dasar bagi penetapan skor angka. Persyaratan pokok bagi tes adalah validitas dan reliabilitas. Metode tes ini digunakan peneliti untuk mengukur hasil belajar siswa dengan menggunakan model pembelajaran Think Talk Write (TTW). Pada tes yang dilakukan menggunakan 20 soal pilihan ganda yang harus dikerjakan pada awal 
pembelajaran sebelum perlakuan (pretest) dan pada akhir pembelajaran (posttest).

Setiap instrumen penelitian harus valid atau sah. Instrumen yang valid berarti alat ukur yang digunakan untuk mendapatkan data itu valid (Sugiyono, 2015:121). Menurut Arikunto (2010:65), "Sebuah tes dikatakan valid apabila tes tersebut mengukur apa yang hendak diukur". Teknik yang digunakan untuk mengukur validitas yaitu teknik korelasi product moment yang dikemukakan oleh Pearson (Arikunto, 2010:69) dengan angka kasar sebagai berikut:

$r_{x y}=\frac{n \sum x y-\left(\sum x\right)\left(\sum y\right)}{\sqrt{\left[n \sum x^{2}-\left(\sum x\right)^{2}\left[n \sum y^{\left.\left.2-\left(\sum y\right)^{2}\right)\right]}\right]\right.}}$

Keterangan:

$r_{x y} \quad$ Koefisiensi korelasi antara variabel $\mathrm{X}$ dan $\mathrm{Y}$, dua variabel yang dikorelasikan

$\sum x y \quad$ Jumlah perkalian $\mathrm{x}$ dengan $\mathrm{y}$

$\sum \mathrm{x} \quad$ : Jumlah seluruh skor $\mathrm{x}$

$\sum \mathrm{y} \quad$ : Jumlah seluruh skor $\mathrm{y}$

$\sum x^{2} \quad$ : Jumlah dari x yang dikuadratkan

$\sum y^{2}$ : Jumlah dari y yang dikuadratkan

$\left(\sum x\right)^{2}$ : Jumlah $\mathrm{x}$ kemudian dikuadratkan

$\left(\sum y\right)^{2}$ : Jumlah y kemudian dikuadratkan

$\mathrm{N} \quad$ : Jumlah subyek yang diteliti

Menurut Arikunto

(2010:75)

koefisien korelasi selalu terdapat antara 1,00 sampai $+1,00$. Namun karena menghitung sering dilakukan pembulatan angka-angka, sangat mungkin diperoleh koefisien lebih dari 1,00. Koefisien negatif menunjukkan hubungan kebalikan sedangkan koefisien negatif menunjukkan hubungan positif. Dengan adanya kesejajaran untuk mengadakan interprestasi mengenai besarnya koefisien korelasi dapat dilihat pada tabel. Sebuah tes dapat dikatakan valid apabila dapat mengungkap data dari variabel yang diteliti secara tepat dan dapat mengukur apa yang hendak diukur. Untuk mengetahui validitas soal digunakan rumus korelasi product moment. Harga $r_{x y}$ yang telah diperoleh kemudian dibandingkan dengan nilai $r_{\text {tabel }}$ product moment dengan taraf $\alpha=5 \%$, jika nilai $r_{x y}>r_{\text {tabel }}$ maka soal dikatakan valid dan soal yang tidak valid jika $r_{x y}<r_{\text {tabel }}$. Selanjutnya hasil koefisien yang diperoleh kemudian diinterprestasikan berdasarkan aturan sebagai berikut:

- Antara 0,800 sampai dengan 1,00 : sangat tinggi

- Antara 0,600 sampai dengan 0,800 : tinggi

- Antara 0,400 sampai dengan 0,600 : cukup

- Antara 0,200 sampai dengan 0,400 : rendah

- Antara 0,00 sampai dengan 0,200 sangat rendah.

Arikunto (2010:221) mengatakan "Reliabilitas" menunjuk pada satu pengertian bahwa sesuatu instrument dapat dipercaya untuk digunakan sebagai alat pengumpulan data karena instrument tersebut sudah baik. Suatu instrumen yang reliabel adalah instrumen bila digunakan beberapa kali untuk mengukur objek yang sama, akan menghasilkan data yang sama (Sugiyono, 2013: 173).

Reliabilitas seluruh tes dapat dicari dengan menggunakan rumus K-R 20 berikut:

$$
r_{11}=\frac{n}{(n-1)}\left\{\frac{S^{2}-\sum p q}{S^{2}}\right\}
$$

Dengan $\quad=\quad S^{2}=\frac{\sum X^{2}-\left(\sum \frac{X}{N}\right)^{2}}{N}$ (3)

Keterangan :

$r_{11}:$ Reliabilitas tes secara keseluruhan

$p \quad$ : Proposi subyek yang menjawab item dengan benar

$q \quad$ : Proposi subyek yang menjawab item dengan salah $(\mathrm{q}=1-\mathrm{p})$

$\sum \mathrm{pq} \quad$ : Jumlah hasil perkalian antara $p$ dengan $q$

n : Banyaknya item

$S \quad$ : Standar deviasi dari tes (standar deviasi adalah akar varians) 
$N$ : Banyaknya subyek yang mengikuti tes (Arikunto, 2016: 115)

Klasifikasi reliabilitas :

$0,800<\mathrm{r} 11 \leq 1,00=$ reliabilitas sangat tinggi

$0,600 \leq \mathrm{r} 11<0.800=$ reliabilitas tinggi

$0,400 \leq \mathrm{r} 11<0,600=$ reliabiltas cukup

$0,200 \leq \mathrm{r} 11<0,400=$ reliabilitas rendah

$0,000 \leq \mathrm{r} 11<0,200=$ reliabailitas sangat rendah.

Tingkat kesukaran butir soal diperlukan untuk mengetahui apakah soal tersebut mudah, sedang, atau sukar. Soal yang baik adalah soal yang tidak terlalu mudah dan tidak terlalu sukar. Soal yang terlalu mudah tidak dapat merangsang siswa untuk mempertinggi yang selalu mudah tidak merangsang siswa untuk mempertinggi usaha memecahkannya. Sebaliknya soal yang terlalu sukar akan menyebabkan siswa menjadi putus asa dan tidak mempunyai semangat mencoba lagi karena di luar jangkauannya (Arikunto, 2016:222). Untuk menghitung tingkat kesukaran soal, dapat digunakan rumus sebagai berikut:

$\mathrm{P}=\frac{B}{J S}$

Keterangan:

$\mathrm{P} \quad$ : Indeks kesukaran

B : Banyaknya siswa yang menjawab soal dengan benar

JS : Jumlah seluruh siswa peserta tes (Arikunto, 2016:223).

Menurut ketentuan yang sering diikuti, indeks kesukaran sering diklasifikasikann sebagai berikut:

Soal dengan $\mathrm{P} 0,00$ sampai 0,30 adalah soal sukar

Soal dengan $\mathrm{P}$ 0,31 sampai 0,70 adalah soal sedang

Soal dengan P 0,71 sampai 1,00 adalah soal mudah

Arikunto (2016:226) mengatakan daya pembeda adalah kemampuan sesuatu soal untuk membedakan antara siswa yang pandai (berkemampuan tinggi) dengan siswa yang bodoh (berkemampuan rendah). Bagi suatu soal yang dapat dijawab benar oleh siswa pandai maupun siswa bodoh, maka soal itu tidak baik karena tidak mempunyai daya pembeda. Demikian pula jika semua siswa baik pandai maupun bodoh tidak dapat menjawab dengan benar. Soal tersebut tidak baik juga karena tidak mempunyai daya pembeda. Soal yang baik adalah soal yang dapat dijawab benar oleh siswa-siswa pandai saja. Adapun rumus yang digunakan untuk mengetahui daya pembeda adalah sebagai berikut:

$D=\frac{B_{A}}{J_{A}}-\frac{B_{B}}{J_{B}}=P_{A}-P_{B}$

Keterangan :

D : Daya pembeda

J : Jumlah peserta tes

$J_{A} \quad$ : Banyaknya peserta kelompok atas

$J_{B} \quad$ : Banyaknya peserta kelompok bawah

$B_{A} \quad$ : Banyaknya peserta kelompok atas yang menjawab benar

$B_{B} \quad$ : Banyaknya peserta kelompok bawah yang menjawab benar

$P_{A} \quad$ : Proporsi peserta kelompok atas yang menjawab benar

$P_{B} \quad$ : Proporsi peserta kelompok bawah yang menjawab benar

(Arikunto, 2016:228-229).

Berikut ini adalah klasifikasi daya pembeda soal, antara lain:

$\mathrm{D}=0,00-0,20$ : jelek

$\mathrm{D}=0,21-0,40:$ cukup

$\mathrm{D}=0,41-0,70$ : baik

$\mathrm{D}=0,71-1,00:$ baik sekali

Uji normalitas digunakan untuk mengetahui apakah sampel yang berasal dari populasi berdistribusi normal atau tidak, pengujian ini dapat dilakukan dengan menggunakan rumus uji Lilliefors, yaitu misalnya kita mempunyai sampel acak dengan hasil pengamatan $x_{1}, x_{2}, \ldots$ $x_{n}$ dengan sampel uji hipotesis. 
Hipotesis

$\mathrm{H}_{\mathrm{o}}$ : sampel berasal dari populasi berdistribusi normal.

$\mathrm{H}_{\mathrm{a}} \quad$ : sampel tidak berasal dari populasi berdistribusi normal.

Jika $\mathrm{L}_{0}<\mathrm{L}_{\text {tabel, }}$ maka $\mathrm{H}_{0}$ diterima.

Jika $\mathrm{L}_{0}>\mathrm{L}_{\text {tabel, }}$ maka $\mathrm{H}_{0}$ ditolak.

Analisis data akhir digunakan untuk membandingkan hasil dari pretest dan posttest agar mengetahui ada tidaknya pengaruh dari perlakuan yang telah dilakukan yaitu pembelajaran IPA dengan model Think Talk Write (TTW). Analisis hasil eksperimen yang menggunakan one group pretest posttest maka dapat dianalisis dengan menggunakan uji beda $(t-$ test), rumusnya adalah:

$$
\mathrm{t}=\frac{\mathrm{Md}}{\sqrt{\left(\frac{\sum \mathrm{xd}^{2}}{\mathrm{~N}(\mathrm{~N}-1)}\right)}}
$$

Keterangan:

Md = Mean dari perbedaan pretest dengan posttest

$\mathrm{xd}=$ Deviasi masing-masing subjek

$(\mathrm{d}-\mathrm{Md})$

$\sum \mathrm{xd}^{2}=$ Jumlah kuadrat deviasi

$\mathrm{N} \quad=$ Subjek pada sampel

d.b. = Ditentukan dengan $\mathrm{N}-1$

(Arikunto, 2010:349-350).

Untuk mengetahui keberhasilan kegiatan belajar mengajar digunakan kriteria ketuntasan belajar sebagai berikut: Ketuntasan Belajar Klasikal

Menurut Sudjana (2005:228) perumusan yang umum untuk uji satu pihak kanan mengenai rata-rata $\mu$ berdasarkan $H_{O}$ dan $\mathrm{H}_{\mathrm{a}}$ adalah:

$$
\begin{aligned}
& H_{o}: \mu<\mu_{o} \\
& H_{1}: \mu \geq \mu_{o}
\end{aligned}
$$

Apabila siswa telah mencapai nilai 65 terhadap materi sistem tata surya maka siswa dinyatakan tuntas.

Hipotesis statistik dalam penelitian ini adalah (1) $\mathrm{H}_{\mathrm{o}}$ : Tidak ada pengaruh penerapan model pembelajaran Think Talk Write (TTW) berbantu media CD Interaktif pada mata pelajaran IPA terhadap hasil belajar siswa kelas VI SD Negeri
Mlatiharjo 02 Semarang Tahun Ajaran $2016 / 2017 t_{\text {hitung }}>t_{\text {tabel }}$. (2) $\mathrm{H}_{\mathrm{a}}$ : Ada pengaruh penerapan model pembelajaran Think Talk Write (TTW) berbantu media CD Interaktif pada mata pelajaran IPA terhadap hasil belajar siswa kelas VI SD Negeri Mlatiharjo 02 Semarang Tahun Ajaran 2016/2017 $t_{\text {hitung }}>t_{\text {tabel }}$.

\section{HASIL DAN PEMBAHASAN}

Penelitian ini dilaksanakan di kelas VI SD Negeri Mlatiharjo 02 Semarang yang berjumlah 40 siswa. Sebelum melakukan penelitian di SD Negeri Mlatiharjo 02 Semarang, dilakukan tes uji instrumen yang dilaksanakan di SD Negeri Purwosari 01 dengan jumlah siswa 26 sebagai sampel uji coba. Dalam penelitian ini soal instrumen yang digunakan berupa soal pilihan ganda sebanyak 30 soal. Teknik yang digunakan dalam penelitian ini adalah pretest dan posttest. Soal pretest dan posttest yang diberikan yaitu 20 soal. Tes awal untuk mengetahui kemampuan awal siswa pada proses pembelajaran sebelum mendapatkan perlakuan adalah dengan menggunakan pretest. Kemudian setelah diberikan perlakuan dengan menggunakan model pembelajaran Think Talk Write (TTW) berbantu media CD Interaktif "Saya Bisa" (Sistem tata surya dan alam semesta), langkah selanjutnya peneliti memberikan posttest yang merupakan tes akhir untuk mengetahui kemampuan siswa setelah diberikan perlakuan. Berikut ini adalah hasil data yang diperoleh pada penelitian dengan teknik pretest dan posttest terhadap Hasil Belajar.

\section{Tabel 2. Data Distribusi Hasil Belajar Pretest dan Posttest}

\begin{tabular}{|l|l|l|}
\hline \multirow{2}{*}{ Keterangan } & \multicolumn{2}{|l|}{ Hasil Belajar } \\
\cline { 2 - 3 } & Pretest & Posttest \\
\hline Jumlah siswa & 40 & \\
\hline Siswa tuntas & 17 & 35 \\
\hline Siswa tidak tuntas & 23 & 5 \\
\hline Rata-rata & 59,125 & 74,5 \\
\hline $\begin{array}{l}\text { Presentase } \\
\text { Ketuntasan }\end{array}$ & $42,5 \%$ & $87,5 \%$ \\
\hline
\end{tabular}


Sumber: Data Hasil Penelitian (2017)

Dari tabel 2 di atas terdapat data distribusi hasil belajar pretest dan posttest. Pada nilai pretest didapatkan nilai rata-rata tes sebesar 59, 125 dengan 23 siswa yang dinyatakan tidak tuntas, dan 17 siswa yang dinyatakan tuntas. Pada posttest nilai ratarata tes yaitu sebesar 74, 5 dengan 5 siswa yang tidak tuntas dan 35 siswa yang dinyatakan tuntas. Nilai presentase ketuntasan pretest dan posttest terhadap hasil belajar siswa meningkat, nilai presentase ketuntasan pretest yaitu 42, 5\% sedangkan nilai presentase ketuntasan posttest yaitu $87,5 \%$. Dari penjelasan diatas dapat diketahui bahwa dengan adanya model pembelajaran Think Talk Write (TTW) berbantu media CD Interaktif "Saya Bisa" (Sistem tata surya dan alam semesta) hasil belajar siswa meningkat.

Berdasarkan data dari perbedaan antara nilai pretest dan posttest meningkat. Pada hasil belajar nilai terendah pretest yaitu 30 sedangkan nilai tertinggi yaitu 95 . Sedangkan nilai terendah posttest yaitu 45 dan nilai teringgi yaitu 100. Pada nilai pretest didapatkan nilai rata-rata adalah 59 sedangkan nilai rata-rata posttest adalah 74. Hal tersebut menunjukkan bahwa adanya perbedaan terhadap hasil belajar pada mata pelajaran Ilmu Pengetahuan Alam (IPA) kelas VI. Yang ditandai dengan nilai rata-rata pretest lebih rendah dari nilai posttest yaitu $59>74$.

Untuk presentase ketuntasan pada nilai pretest dan posttest yaitu terdapat kenaikan pada pretest sebesar 42,5\% dan presentase ketuntasan pada posttest yaitu sebesar $87,5 \%$. Jadi, dapat disimpulkan bahwa nilai pretest dan posttest siswa untuk hasil belajar siswa kelas VI meningkatan. Dengan menggunakan model pembelajaran Think Talk Write (TTW) berbantu media CD Interaktif "Saya Bisa" (Sistem tata surya dan alam semesta) dapat meningkatkan hasil belajar siswa. Analisis penelitian ini dibagi menjadi dua tahap yaitu sebagai berikut:

1) Uji Normalitas Awal
Rumus Liliefors dapat digunakan pada hasil pretest dan posttest. Uji normalitas dengan taraf signifikan $5 \%$. Kriteria dalam uji normalitas ini adalah: Lo < L Label maka sampel berasal dari populasi berdistribusi normal.

Lo > L tabel maka sampel berasal dari populasi tidak berdistribusi normal.

\section{Tabel 3. Data Normalitas Awal Hasil Belajar Pretest}

\begin{tabular}{|l|l|l|l|}
\hline Data & $\mathrm{L}_{0}$ & $1_{\text {tabel }}$ & Simpulan \\
\hline Pretest & 0,0812 & 0,140 & $\begin{array}{l}\text { Variabel } \\
\text { berdistribusi } \\
\text { normal }\end{array}$ \\
\hline Posttest & 0,1312 & 0,140 & $\begin{array}{l}\text { Variabel } \\
\text { berdistribusi } \\
\text { normal }\end{array}$ \\
\hline
\end{tabular}

Dari tabel di atas dapat dijelaskan bahwa taraf nyata $a=5 \%$, pada nilai pretest terhitung Lhitung $=0,0812$, Ltabel $=$ 0,140 maka sesuai dengan kriteria uji normalitas bahwa Lhitung < Ltabel yaitu $0,0812<0,140$ maka Ho diterima, sehingga dapat disimpulkan bahwa data pretest berasal dari populasi yang berdistribusi normal. Sedangkan untuk nilai posttest diperoleh data perhitungan Lhitung $=0,1312$, Ltabel yaitu 0,140 maka sesuai dengan kriteria uji normalitas, Lhitung < Ltabel yaitu $0,1312<0,140$ maka Ho diterima, sehingga dapat disimpulkan bahwa data nilai pretest berasal dari populasi berdistribusi normal. Dari hasil kedua data tersebut dapat disimpulkan bahwa data pretest dan posttest berdistribusi normal.

2) Uji Normalitas Akhir

Untuk mengetahui normalitas sampel dari populasi ini peneliti menggunakan rumus Liliefors, pada taraf signifikan $5 \%$ dan uji normalitas digunakan pada hasil pretest dan posttest. Kriteria dalam uji normalitas ini adalah: Lo < Ltabel maka sampel berasal dari populasi berdistribusi normal,

Lo > Ltabel maka sampel berasal dari populasi tidak berdistribusi normal. 
Tabel 4. Data Normalitas Awal Hasil Belajar Pretest

\begin{tabular}{|l|l|l|l|}
\hline Data & $\mathrm{L}_{0}$ & $1_{\text {tabel }}$ & Simpulan \\
\hline Pretest & 0,0812 & 0,140 & $\begin{array}{l}\text { Variabel } \\
\text { berdistribusi } \\
\text { normal }\end{array}$ \\
\hline Posttest & 0,1312 & 0,140 & $\begin{array}{l}\text { Variabel } \\
\text { berdistribusi } \\
\text { normal }\end{array}$ \\
\hline
\end{tabular}

Dari tabel di atas dapat dijelaskan bahwa taraf nyata $\mathrm{a}=5 \%$, pada data pretest terhitung Lhitung $=0,0812$, Ltabel $=0,140$ maka sesuai dengan kriteria uji normalitas bahwa Lhitung < Ltabel yaitu 0,0812 < 0,140 maka Ho diterima, sehingga dapat disimpulkan bahwa data pretest berasal dari populasi yang berdistribusi normal. Sedangkan untuk data posttest diperoleh data perhitungan Lhitung $=0,1312$, Ltabel yaitu 0,140 maka sesuai dengan kriteria uji normalitas, Lhitung < Ltabel yaitu 0,1312 $<0,140$ maka Ho diterima, sehingga dapat disimpulkan bahwa data nilai posttest berasal dari populasi berdistribusi normal. Dari hasil kedua data tersebut dapat disimpulkan bahwa nilai pretest dan posttest berdistribusi normal. Perhitungan selengkapnya dapat dilihat pada lampiran.

Hasil penelitian dengan menggunakan media pembelajaran Think Talk Write (TTW) berbantu media CD Interaktif "Saya Bisa" (Sistem tata surya dan alam semesta) menunjukan bahwa rata-rata nilai pretest adalah 59,125. Sedangkan rata-rata nilai posttest adalah 74,5. Hal ini dapat disimpulkan bahwa media pembelajaran Think Talk Write (TTW) berbantu media CD Interaktif "Saya Bisa" (Sistem tata surya dan alam semesta) dapat meningkatkan hasil belajar kelas VI pada mata pelajaran Ilmu Pengetahuan Alam (IPA).

Berdasarkan hasil pretest dan posttest siswa kelas VI SD Negeri Mlatiharjo 02 Semarang sebagai subjek penelitian dilakukan uji hipotesis untuk membuktikan penerapan model pembelajaran Think Talk Write (TTW) berbantu media CD Interaktif pada mata pelajaran IPA terhadap hasil belajar siswa kelas VI SD Negeri Mlatiharjo 02 Semarang tahun ajaran 2016/2017. Ketuntasan hasil belajar siswa dapat dilihat dari nilai rata-rata dan perbedaan pada nilai pretest dan posttest yang diperoleh siswa. Hipotesis statistik untuk keperluan $t$ test adalah sebagai berikut:

$H_{o}$ : Tidak ada perbedaan yang signifikan antara hasil pembelajaran pretest dan posttest.

$H_{a}$ : Ada perbedaan yang signifikan antara hasil pembelajaran pretest dan posttest.

Kriteria pengujian $H_{o}$ diterima apabila $t_{\text {hitung }}>t_{\text {tabel }}$ dengan $\mathrm{db}=\mathrm{n}$ $1=40-1=39$. Untuk $\alpha=5 \%$ maka harga $t_{\text {tabel }} 7,252$ dan $t_{\text {tabel }} 1,684$. Dari perhitungan uji t diperoleh $t_{\text {hitung }}>t_{\text {tabel }}$ yaitu $7,252>1,684$. Dengan demikian maka $H_{o}$ ditolak dan $H_{a}$ diterima. Jadi ada perbedaan yang signifikan antara hasil belajar pretest dan posttest setelah menggunakan model pembelajaran Think Talk Write (TTW) berbantu media CD Interaktif pada mata pelajaran IPA terhadap hasil belajar siswa kelas VI SD Negeri Mlatiharjo 02 Semarang tahun ajaran 2016/2017.

1) Ketuntasan Belajar Klasikal

Menurut Sudjana (2005:228) perumusan yang umum untuk uji satu pihakkanan mengenai rata-rata $\mu$ berdasarkan $H_{O}$ dan $\mathrm{H}_{\mathrm{a}}$ adalah:

$$
\begin{aligned}
& H_{o}: \mu<\mu_{o} \\
& H_{1}: \mu \geq \mu_{o}
\end{aligned}
$$

Apabila siswa telah mencapai nilai 65 terhadap materi sistem tata surya maka siswa dinyatakan tuntas. Jika siswa telah mendapatkan nilai sekurang-kurangnya 65 terhadap materi Sistem tata surya dengan demikian siswa tersebut telah mencapai ketuntasan belajar. Ketuntasan belajar siswa dalam proses pembelajaran dengan menggunakan model pembelajaran Think Talk Write (TTW) berbantu media CD Interaktif. Dari 40 siswa terdapat 35 siswa 
yang mendapatkan nilai tuntas, dan 5 siswa yang belum tuntas.

\section{Tabel 5. Data Ketuntasan Belajar Siswa (Individual)}

\begin{tabular}{|l|l|l|}
\hline \multirow{2}{*}{$\begin{array}{l}\text { Jumlah } \\
\text { Siswa }\end{array}$} & \multicolumn{2}{|l|}{ Ketuntasan Siswa } \\
\cline { 2 - 3 } & Tuntas & Tidak Tuntas \\
\hline 40 & 35 & 5 \\
\hline
\end{tabular}

Apabila sekurang-kurangnya $65 \%$ dari siswa berhasil mencapai tingkat penguatan yang ditetapkan maka kelas tersebut dinyatakan tuntas. Hal tersebut dapat dinyatakan tuntas dapat dilihat pada tabel berikut:

\section{Tabel 6. Data Ketuntasan Belajar Klasikal}

\begin{tabular}{|l|l|}
\hline Sumber Variasi & Kelas \\
\hline Jumlah siswa tuntas & 35 \\
\hline Jumlah siswa keseluruhan & 40 \\
\hline Ketuntasan & $87,5 \%$ \\
\hline
\end{tabular}

\section{Pembahasan}

Pada penelitian ini peneliti memilih menggunakan model pembelajaran Think Talk Write (TTW) berbantu media CD Interaktif, karena model pembelajaran ini dapat meningkatkan keaktifan siswa dalam proses pembelajaran. Dengan menggunakan model pembelajaran ini siswa mampu berfikir (Think), berbicara (Talk), dan menulis (Write). Dalam model pembelajaran Think Talk Write (TTW) dimulai dari keterlibatan siswa dalam berpikir atau berdialog dengan dirinya sendiri setelah proses membaca, selanjutnya berbicara dan membagi ide dengan temannya sebelum menulis. Suasana ini lebih efektif jika dilakukan dalam kelompok heterogen dengan 3-5 siswa. Dalam kelompok ini siswa diminta membaca, membuat catatan kecil, menjelaskan, mendengarkan dan membagi ide bersama teman kemudian mengungkapkannya melalui tulisan. Aktivitas berpikir, berbicara dan menulis ini adalah salah satu bentuk aktivitas belajar mengajar yang memberikan peluang kepada siswa untuk berpartisipasi aktif. Tahapan-tahapan yang dilakukan dalam pembelajaran menggunakan tipe ini adalah berpikir (Think), berbicara (Talk), dan menulis (Write).

Data distribusi hasil belajar pretest dan posttest didapatkan nilai rata-rata tes sebesar 59,125 dengan 23 siswa yang dinyatakan tidak tuntas, dan 17 siswa yang dinyatakan tuntas. Pada posttest nilai ratarata tes yaitu sebesar 74,5 dengan 5 siswa yang tidak tuntas dan 35 siswa yang dinyatakan tuntas. Nilai presentase ketuntasan pretest dan posttest terhadap hasil belajar siswa meningkat, nilai presentase ketuntasan pretest yaitu $42,5 \%$ sedangkan nilai presentase ketuntasan posttest yaitu $87,5 \%$. Dari penjelasan di atas dapat diketahui bahwa dengan adanya model pembelajaran Think Talk Write (TTW) berbantu media CD Interaktif "Saya Bisa" (Sistem tata surya dan alam semesta) hasil belajar siswa meningkat.

Dari uji normalitas akhir dapat dijelaskan bahwa taraf nyata $a=5 \%$, pada data pretest terhitung Lhitung $=0,0812$, Ltabel=0,140 maka sesuai dengan kriteria uji normalitas bahwa Lhitung < Ltabel yaitu $0,0812<0,140$ maka Ho diterima, sehingga dapat disimpulkan bahwa data pretest berasal dari populasi yang berdistribusi normal. Sedangkan untuk data diperoleh data posttest perhitungan Lhitung=0,1312 Ltabel yaitu 0,140 maka sesuai dengan kriteria uji normalitas, Lhitung < Ltabel yaitu $0,1312<0,140$ maka Ho diterima, sehingga dapat disimpulkan bahwa data nilai posttest berasal dari populasi berdistribusi normal. Dari hasil kedua data tersebut dapat disimpulkan bahwa nilai pretest dan posstest berdistribusi normal.

Berdasarkan analisis data dari uji hipotesis, maka diperoleh hasil perhitungan pada model pembelajaran Think Talk Write (TTW) berbantu media CD Interaktif "Saya Bisa" (Sistem tata surya dan alam semesta) sebagai berikut: (1) Skor hasil belajar siswa pada posttest 
dengan menggunakan model pembelajaran Think Talk Write (TTW) berbantu media CD Interaktif lebih tinggi dari pada hasil pretest. (2) Presentase ketuntasan klasikal pada posttest dengan menggunakan model pembelajaran Think Talk Write (TTW) berbantu media CD Interaktif lebih tinggi dari pada hasil pretest. (3) Ada perbedaan signifikan pada pretest dan posttest pada hasil belajar siswa dengan menggunakan model pembelajaran Think Talk Write (TTW) berbantu media CD Interaktif di SD Negeri Mlatiharjo 02 Semarang Tahun Ajaran 2016/2017 dengan rata-rata pretest hasil belajar 59,125 dan posttest 74,5.

\section{PENUTUP}

Berdasarkan hasil penelitian dan pembahasan, maka dapat disimpulkan bahwa penerapan model pembelajaran Think Talk Write (TTW) berbantu media CD Interaktif pada mata pelajaran IPA terhadap hasil belajar siswa kelas VI SD Negeri Mlatiharjo 02 Semarang Tahun Ajaran 2016/2017 adalah: 1) hasil uji t menunjukkan bahwa analisis $t_{\text {test }}$ diperolah $t_{\text {hitug }}$ sebesar 7,252 sedangkan $t_{\text {tabel }}$ dengan $\mathrm{db} \mathrm{N}-1=40-1=39$, dan taraf signifikan 0,05 sebesar 1,684. Karena thitung $>t_{\text {tabel }}$ yaitu 7,252> 1,684 maka $\mathrm{H}_{0}$ ditolak dan $\mathrm{H}_{\mathrm{a}}$ diterima. Jadi dapat disimpulkan bahwa ada pengaruh penerapan model pembelajaran Think Talk Write (TTW) berbantu media CD Interaktif pada mata pelajaran IPA terhadap hasil belajar siswa kelas VI SD Negeri Mlatiharjo 02 Semarang Tahun Ajaran 2016/2017. 2) Berdasarkan penelitian terdapat perbedaan yang signifikan antara nilai pretest dan posttest. Nilai rata-rata posttest lebih besar yaitu 74,5 dibandingkan dengan nilai ratarata pretest yaitu 59,125. Sehingga dapat kita ketahui ada peningkatan nilai posttest dibandingkan nilai pretest.

Berdasarkan kesimpulan yang telah dipaparkan maka peneliti merumuskan beberapa saran: 1) Model pembelajaran Think Talk Write (TTW) berbantu media CD Interaktif dapat meningkatkan hasil belajar siswa, oleh karena itu guru harus mampu menerapkan model pembelajaran
Think Talk Write (TTW) berbantu media CD Interaktif "Saya Bisa" (Sistem tata surya dan alam semesta) dengan baik agar siswa lebih semangat dan berantusias dalam mengikuti pembelajaran di kelas. 2) Guru dapat menggunakan model pembelajaran yang lebih bervariasi sehingga hasil belajar siswa dapat meningkat. 3) Diharapkan model pembelajaran Think Talk Write (TTW) berbantu media CD Interaktif "Saya Bisa" (Sistem tata surya dan alam semesta) ini dapat digunakan oleh guru SD Negeri Mlatiharjo 02 Semarang.

\section{DAFTAR PUSTAKA}

Arikunto, Suharsimi. (2010). Prosedur Penelitian, edisi revisi. Jakarta: Rineka Cipta.

Arikunto, Suharsimi. (2016). Dasar-Dasar Evaluasi Pendidikan, edisi 2. Jakarta: Bumi Aksara.

Aunurrahman. (2009). Belajar dan Pembelajaran. Bandung: Alfabeta

Hamdayama, J. (2015). Model dan Metode Pembelajaran Kreatif dan Berkarakter. Bogor: Ghalia Indonesia.

Huda, M. (2014). Model-model Pengajaran dan Pembelajaran. Yogyakarta: Pustaka Pelajar.

Iru, L. dan Arisi, L. O. S. (2012). Analisis Penerapan Pendekatan, Metode, Strategi, dan Model-model Pembelajaran. Yogjakarta: Multi Presindo.

Siregar, E. dan Nara, H. (2014). Teori Belajar dan Pembelajaran. Bogor: Ghalia Indonesia.

Sudjana. (2005). Metoda Statistika. Bandung: Tarsito.

Sugiyono. (2010). Metode Penelitian Kuantitatif Kualitatif dan $R \& D$. Bandung: Alfabeta.

(2013). Metode Penelitian Pendidikan. Bandung: Alfabeta. (2015). Metode Penelitian Pendidikan. Bandung: Alfabeta. (2016). Metode Penelitian Pendidikan. Bandung: Alfabeta. 
Suhartanti, D. (2008). Ilmu Pengetahuan Alam. Jakarta: Putra Nugraha.

Ysh, S. dan Maryadi. (2015). Evaluasi Hasil Belajar Pengetahuan dan Teknik. Yogyakarta: Magnum Pustaka Utama. 